\title{
ETFA wt Allele
}

National Cancer Institute

\section{Source}

National Cancer Institute. ETFA wt Allele. NCI Thesaurus. Code C131570.

Human ETFA wild-type allele is located within 15q24.2-q24.3 and is approximately $96 \mathrm{~kb}$ in length. This allele, which encodes electron transfer flavo protein subunit alpha, mitochondrial protein, is involved in cellular respiration. Mutation of the gene is associated with glutaric aciduria $2 \mathrm{~A}$. 